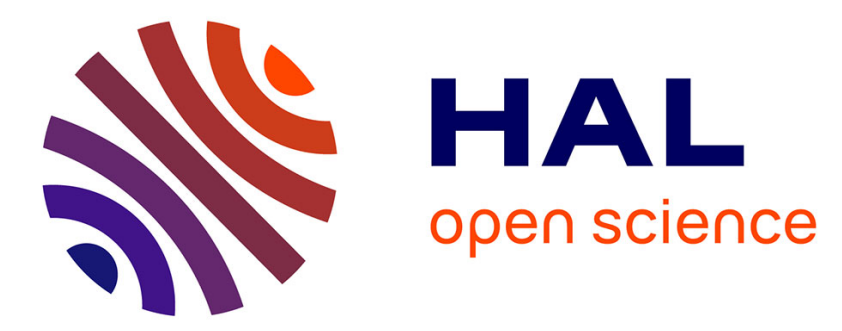

\title{
Exploring the Potential of Groundwater Markets in Agriculture: Results of a Participatory Evaluation in Five French Case Studies
}

Cécile Hérivaux, Jean-Daniel Rinaudo, Marielle Montginoul

\section{To cite this version:}

Cécile Hérivaux, Jean-Daniel Rinaudo, Marielle Montginoul. Exploring the Potential of Groundwater Markets in Agriculture: Results of a Participatory Evaluation in Five French Case Studies. Water Economics and Policy, 2020, 6 (1), pp.1950009. 10.1142/S2382624X19500097 . hal-02302600

\section{HAL Id: hal-02302600 https: / hal-brgm.archives-ouvertes.fr/hal-02302600}

Submitted on 1 Oct 2019

HAL is a multi-disciplinary open access archive for the deposit and dissemination of scientific research documents, whether they are published or not. The documents may come from teaching and research institutions in France or abroad, or from public or private research centers.
L'archive ouverte pluridisciplinaire HAL, est destinée au dépôt et à la diffusion de documents scientifiques de niveau recherche, publiés ou non, émanant des établissements d'enseignement et de recherche français ou étrangers, des laboratoires publics ou privés. 


\title{
Exploring the potential of groundwater markets in agriculture: results of a participatory evaluation in
}

\section{five French case studies}

\author{
Cécile Hérivaux $^{\mathrm{a}, *}$, Jean-Daniel Rinaudo ${ }^{\mathrm{b}}$, Marielle Montginoul ${ }^{\mathrm{c}}$ \\ a BRGM, Univ. Montpellier, 1039 rue de Pinville, 34000 Montpellier, France, +33.4.67.15.79.71, c.herivaux@brgm.fr

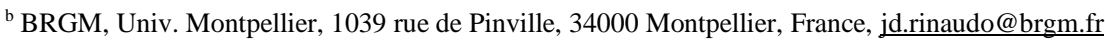 \\ c IRSTEA, UMR G-Eau, 361 rue Jean-François Breton, BP 5095, 34196 Montpellier Cedex 5, France, marielle.montginoul@irstea.fr \\ * Corresponding author
}

\begin{abstract}
We used a participatory foresight method for assessing if, and how, groundwater markets could be incorporated into local groundwater management policies. We propose an institutional setup adapted to the French water policy context, with a cap and trade scenario introducing groundwater markets in the agricultural sector between now and the 2035 horizon. Considering the local hydrogeological characteristics, we applied this method to five French groundwater basins, and then analysed the public perception of our scenario by organizing 16 half-day workshops, involving a total of 44 institutional stakeholders and 80 farmers. Overall, almost half of the participants were opposed to the introduction of groundwater markets for various ethical, economic and technical reasons. Many of the preconditions for water trading are still far from being met, and major social and economic risks are anticipated. However, our results also suggest that there might be scope for developing groundwater markets compatible with French water policy at a local scale; the preconditions for this are that specific local hydrogeological and agricultural situations are taken into account, and that a participatory process is developed, involving institutional stakeholders and farmers.
\end{abstract}

\section{Keywords}

Water market; Cap and trade; Participatory foresight; Groundwater; Agriculture; Irrigation; France.

\section{Acknowledgements}

This work was financially supported by ONEMA, as part of the Water Cap \& Trade project (Era Net programme on Integrated Water Resources Management). The preparatory work for this chapter was made possible thanks to financial support from BRGM. We would like to thank the two anonymous reviewers for their helpful suggestions. 


\section{INTRODUCTION}

Since the mid-1990s, mainstream environmental and resource economists have unfailingly promoted the development of water markets for reallocating water resources and regulating pollution control (Rosegrant and Binswanger, 1994; Livingstone, 1995). This approach is based on establishing an aggregate cap on water-resource abstraction, on allocating individual abstraction rights to users, and on making these rights tradable. The argument, reflecting standard economic theory, is that markets are more cost-effective than command-and-control regulation for reaching an optimal allocation of limited renewable stocks, and that they are more flexible for adapting to an ever-changing economic and environmental context (Young, 2014). The implementation of a system of tradable water rights was strongly supported by international financial institutions in the 1990s (World Bank, 1993; Thobani, 1997), and has been adopted and implemented in various developed and developing countries (Grafton et al., 2011; Easter and Huang, 2014). Historically, water markets were first established for managing surfacewater resources, in regulated river basins with significant infrastructure for storing and transferring water. More recently, their use has been extended to groundwater resources in several western states of the USA and Australia (Thompson et al., 2009; Lawson et al., 2010; Skurray et al., 2013; Brozovic and Young, 2014; Wheeler et al., 2016).

Water markets, when applied to groundwater management, do not always function as predicted, because several barriers may impede their development or operation (Bauer, 1997; 2012; Skurray et al., 2012; 2013; Easter and Huang, 2014; Wheeler et al., 2016). In many groundwater basins where water markets were introduced, transactions remain limited and far below expected levels. This may be for different reasons, including an inadequate institutional framework, high transaction costs, overestimated caps (initial over-allocation), and problems of compliance and enforcement (Brozovic and Young, 2014). This has led to the need for a new approach to water markets by policy makers and managers.

It is thus clear that water markets are not a one-fits-all miracle tool that can be used by simply following a standard recipe from a Resource Economics handbook, and there is a growing recognition that these mechanisms cannot always be adapted to suit any hydrological and institutional context (Green Nylen et al., 2017; Babbitt et al., 2017; Holley and Sinclair, 2018). Furthermore, where they are deemed suitable, they must be carefully adapted to local socio-economic, institutional, environmental and cultural characteristics (Babbitt et al., 2017). As stressed by Tisdell and Ward (2003), water markets are unlikely to function optimally if social and cultural attitudes to 
trade are not duly considered. Stakeholders thus must be involved in the design of an institutional market set-up that best meets community needs.

Nonetheless, very little research has assessed or designed water markets with an active participation of stakeholders, in countries where such instruments are still in their infancy. Some studies have developed analytical frameworks for guiding allocation reforms (OECD, 2015), or, more specifically, for assessing if the administrative conditions for developing water-trading arrangements are met (Wheeler et al., 2017). While they represent a useful resource, such frameworks have not been used (to our knowledge) in the participatory design of water markets. Other studies have used qualitative or quantitative surveys and workshops for analysing the stakeholders' willingness to adopt a new water-market instrument (Zhang, 2007; Giannocaro et al., 2013; 2016, Lumbroso et al., 2014; Rahimova et al., 2016), but then they did not involve stakeholders in the construction of a policy scenario.

Our research aimed at filling this gap by using a truly participatory research methodology, for assessing if and how water markets can be incorporated in a local groundwater management policy. A key assumption was that, given the political dimension of market instruments (Heinmiller, 2007), engaging all stakeholders involved in water use and management should help identifying three points: 1) The potential strengths and weaknesses of various forms of water-market mechanisms; 2) The preconditions for their effective implementation in each specific context; and 3) The potential barriers to acceptance and development. We also assumed that a combination of expert and lay knowledge will help when designing highly innovative institutional set-ups (Rinaudo and Garin, 2005; Rinaudo et al., 2012). Stakeholder participation in the design of water-management instruments makes them more legitimate and thus more acceptable (OECD, 2015; Rinaudo et al., 2016b).

A second key assumption was that a long-term perspective is necessary when planning a groundwater market instrument with stakeholders (Babbitt et al., 2017); generally, several changes must be made to the water policy before trading can be considered. Therefore, we introduced the groundwater market as part of a broader cap and trade scenario through scenario workshops. Our study focused on France, where the idea of developing water markets has been discussed since the early 2000's, either in general terms or using modelling (Strosser and Montginoul, 2001; Rinaudo et al., 2016a), but without involving stakeholders. We then tested the proposed methodology on five French groundwater basins.

The paper is organized as follows: Section 2 presents the methodological framework used for designing a tailor-made groundwater cap and trade policy scenario, and for assessing how it is perceived by local stakeholders. Section 3 provides background information on the French context and presents the cap and trade 
scenario and how it was adapted to each case study. Section 4 analyses and discusses the results of the scenario workshops. Section 5 concludes on the relevance of developing groundwater markets in the French context.

\section{METHODOLOGICAL FRAMEWORK AND CASE STUDIES}

The methodological approach comprised four main steps described below.

\subsection{Step 1. Designing a cap and trade scenario}

First, we designed a cap and trade scenario adapted to the French water policy context, which describes a potential pathway for allowing groundwater trading in the agricultural sector in France. In line with Wheeler et al. (2017) and OECD (2015), and based on a review of existing cap and trade policies in Chile (Galaz, 2004; Bauer, 2012), Spain (Rey et al., 2014), the USA (Howe, 2002; Thompson et al., 2009) and Australia (Boyd and Brumley, 2004: Lawson et al., 2010; Hamilton and Smithson, 2010; GHD et al., 2011), we identified three main components of the scenario (Fig. 1) and analysed the range of possible options for their definition. These components are summarized in Figure 1 and in the paragraphs below.

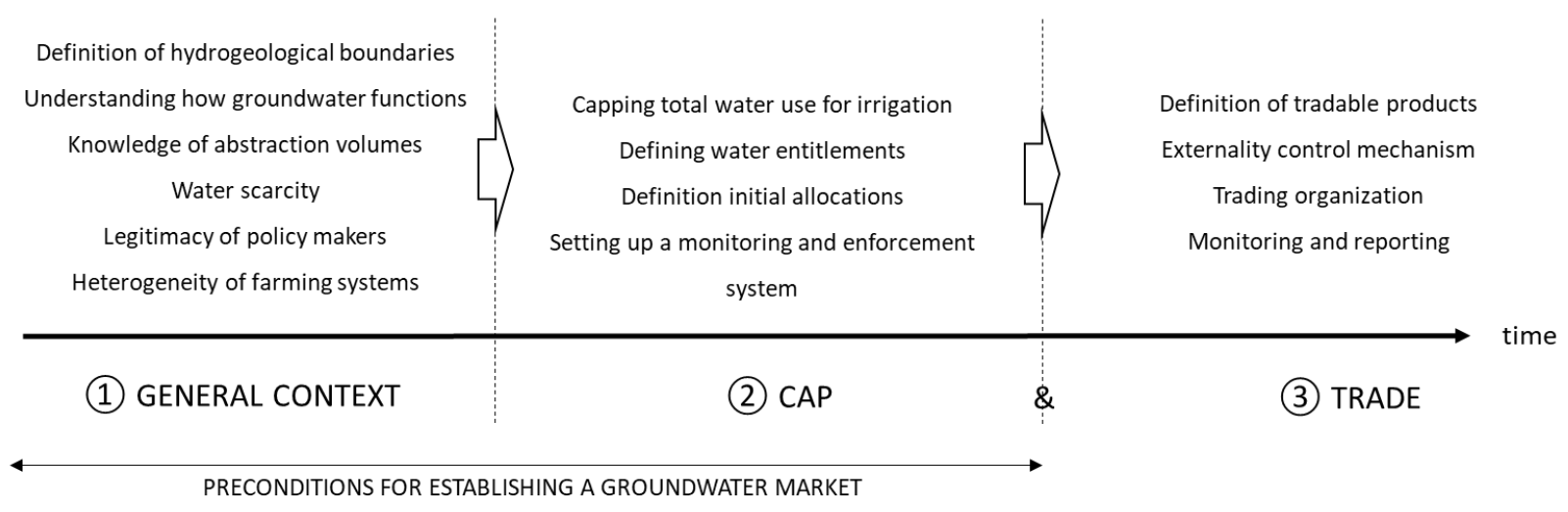

Fig. 1 Key components for designing a cap and trade policy scenario

\subsubsection{General context}

Several basic general conditions should be met before allowing farmers to trade water. First, the resource should be clearly delimited, its functioning should be understood, and abstraction properly monitored. This is essential for setting the cap, but also for controlling environmental consequences (Skurray et al., 2012).

The second condition is that water should be scarce, and considered as such by users and other stakeholders. Studies have shown that there may be a gap between experts' and users' perceptions regarding resource scarcity (Rinaudo et al., 2016b). 
The third condition is that the proposed mechanism and the policymakers promoting it should be regarded as legitimate, i.e. having the users' trust and support. Compliance with the newly established allocation mechanism is clearly dependent upon these conditions.

Finally, trade only makes sense if there is a difference in marginal product value for the different users, generating opportunities for "win-win" voluntary exchanges of water-use rights. All these conditions must be met before policymakers can begin to envisage the possibility of implementing a cap and trade water policy.

\subsubsection{Capping total water use for irrigation, defining water entitlements and initial allocations}

Before implementing a cap and trade policy in the agricultural sector, total water use for irrigation (volume or total pumping rate) must be capped first. Two types of abstraction limits are needed (OECD, 2015): a long-term limit (the "cap") defines the maximum amount of water that can be abstracted from the groundwater resource; a shortterm limit (the "adjusted cap") defines the amount of water that can be abstracted within a specified period (e.g., a season or a year), depending on meteorological conditions and hydrological status. In parallel, "water entitlements" should clearly specify individual water-use rights and be aligned with the cap. "Water allocations" can be used for determining the amount of water that an entitlement holder is permitted to abstract within a specified period (OECD, 2015). Individual water allocations are aligned with the adjusted cap. The allocated initial volumes may be based on historical authorized water use, adjusted as a function of the reductions imposed by capping. An appropriate metering and penalty system should ensure satisfactory enforcement and compliance.

\subsubsection{Defining water-trading rules}

Once caps and individual volumes have been set, policymakers may allow water users to trade their water entitlements (permanent transfer) or water allocations within a given period (temporary transfer). Trade may be limited to the agricultural sector or authorized between sectors. Controlling environmental and social externalities is a major concern for policymakers and managers when water trading occurs, but trade-management rules can serve to limit the social and environmental effects. Trade regulation is highly dependent upon the hydrological, economic and social contexts, but it can be organized in diverse ways to ensure that it will be compatible with the existing institutional framework. For example, trade can be based on bilateral negotiations between buyers and sellers, which requires minimal supervision and may, or may not, involve brokers. 


\subsection{Step 2. Adapting the cap and trade scenario to local case studies}

We selected five basins where groundwater use for irrigation is significant, all being representative of the diversity of hydrogeological and agricultural situations in France. Table 1 summarizes the key characteristics of the five case studies.

From April 2012 to March 2013, a dozen interviews with stakeholders (administrations, users, NGOs) were conducted for identifying the groundwater-management problems, issues and options in each basin. We also collected and analysed all existing studies and planning documents. This in-depth analysis of current water management in the five basins provided the basis not only for developing a theoretical cap and trade scenario, but also for selecting the institutional set-up that appeared to be the most appropriate for each basin.

Table 1. Description of case studies in 2013 (more details in Figureau et al. (2015))

\begin{tabular}{|c|c|c|c|c|c|}
\hline & $\begin{array}{c}\text { Lyonnais } \\
\text { aquifer }\end{array}$ & $\begin{array}{c}\text { Tarn-et- } \\
\text { Garonne plain }\end{array}$ & Serre basin & Clain basin & $\begin{array}{c}\text { Valence } \\
\text { plain }\end{array}$ \\
\hline Basin size (ha) & 40,000 & 94,000 & 163,000 & 320,000 & 48,000 \\
\hline $\begin{array}{l}\text { Hydrogeology } \\
\text {. Inertia } \\
\text {. Aquifer type }\end{array}$ & $\begin{array}{c}\text { High } \\
\text { Fluvio-glacial } \\
\text { corridors }\end{array}$ & $\begin{array}{c}\text { Intermediate } \\
\text { Alluvial } \\
\text { aquifer }\end{array}$ & $\begin{array}{l}\text { Intermediate } \\
\text { Chalk aquifer }\end{array}$ & $\begin{array}{l}\text { Low } \\
\text { Karstic } \\
\text { aquifer }\end{array}$ & $\begin{array}{l}\text { Low } \\
\text { Alluvial } \\
\text { aquifer }\end{array}$ \\
\hline $\begin{array}{l}\text { Agriculture } \\
\text {. Number of irrigating farms } \\
\text {. Irrigated area (ha; \% UAA*) } \\
\text {. Main types of crops }\end{array}$ & $\begin{array}{c}320 \\
7,000(35 \%) \\
\text { Cereals, oil } \\
\text { and protein } \\
\text { crops } \\
\end{array}$ & $\begin{array}{c}550 \\
22,000(25 \%) \\
\text { Fruit, cereals }\end{array}$ & $\begin{array}{c}95 \\
4,000(2.5 \%) \\
\text { Vegetables, } \\
\text { cereals }\end{array}$ & $\begin{array}{l}400 \\
28,000(11 \%) \\
\text { Cereals }\end{array}$ & $\begin{array}{l}125 \\
9,800(40 \%) \\
\text { Corn, fruit, } \\
\text { vegetables }\end{array}$ \\
\hline $\begin{array}{l}\text { Agricultural groundwater abstraction } \\
\text {. Mean annual volume (million } \mathrm{m}^{3 /} \text { year) } \\
\text {. Type of abstraction (individual/ } \\
\text { collective) }\end{array}$ & $\begin{array}{c}9 \\
\text { Collective }\end{array}$ & $\begin{array}{c}29 \\
\text { Individual }\end{array}$ & $\begin{array}{c}6 \\
\text { Individual }\end{array}$ & $\begin{array}{c}25 \\
\text { Individual }\end{array}$ & $\begin{array}{c}5 \\
\text { Individual }\end{array}$ \\
\hline $\begin{array}{l}\text { Water scarcity } \\
\text { Crisis and restrictions in groundwater } \\
\text { use for irrigation } \\
\text {. Surface water as an alternative resource }\end{array}$ & $\begin{array}{l}\text { Rare } \\
\text { None }\end{array}$ & $\begin{array}{l}\text { Occasional } \\
\text { Dense surface } \\
\text { irrigation } \\
\text { network }\end{array}$ & $\begin{array}{c}\text { Rare } \\
\text { Very limited }\end{array}$ & $\begin{array}{c}\text { Frequent } \\
\text { Very limited }\end{array}$ & $\begin{array}{l}\text { Frequent } \\
\text { Dense } \\
\text { surface } \\
\text { irrigation } \\
\text { network }\end{array}$ \\
\hline
\end{tabular}

* UAA: Utilized Agricultural Area.

We evaluated how water policy is likely to evolve in each case study, if the reform is implemented over a decade or more. Our narrative descriptions were presented as press releases, giving details of the different reform steps to be implemented between 2020 and 2035. As a result of the field work, we could introduce very local references into the policy scenarios. Four alternative groundwater policy instruments were successively discussed during the workshops, the last being groundwater markets. We included several contrasted policy options (market, community, or State centred), to ensure that the research team was not perceived as being ideologically biased. This paper only deals with the groundwater-market-oriented policy option. Readers interested in the other three policy options will find more information in Figureau et al. (2015). 


\subsection{Step 3. Scenario workshops}

Many ways exist of involving stakeholders in the design of a new instrument, including focus groups, consensus conferences and citizens' juries. For our research we chose scenario workshops, following the participative foresight method described by Figureau et al. (2015). This allowed a critical analysis of the proposed cap and trade policy scenario together with stakeholders. The objective was to identify and draw on collective expertise (users, water managers, regulators), by comparing their perception of the proposed policy. In each case study, we created two or three stakeholder groups: one large group assembling representatives of the main institutional stakeholders (10 to 15 participants, including local and regional government representatives, farming representatives, water agencies, environmental associations and geological surveys), and one or two farmer groups (5 to 15 participants each). We deliberately separated farmers and other stakeholders, to encourage farmers to express their views more readily, which helped overcoming the deep mistrust that some may have for institutional stakeholders in France. Overall, we organized 16 workshops lasting 4-5 hours each, from June 2012 to March 2013, and collected information from 124 participants (44 institutional stakeholders and 80 irrigating farmers).

The workshops started with a discussion of current groundwater-management rules, to ensure that existing institutional and policy frameworks were clearly understood. We then presented a baseline situation showing how rules and the general context could evolve by 2020. Following this, we introduced the first two components illustrated on Figure 1. After discussing the three instruments described in Figureau et al. (2015), we broached the subject of a groundwater market mechanism (third component on Figure 1).

Before the discussion, the participants were invited to fill in a questionnaire, to express their first impressions of the proposed instrument. They briefly described their position on groundwater trading (opposed, favourable under certain conditions, or totally favourable), and gave their own estimate of the percentage of groundwater volumes that would be traded if the scenario was introduced (negligible, $5-10 \%, 10-30 \%$, over $30 \%$ ). They also stated whether they would accept buying or selling water, and, if so, occasionally or regularly. Finally, we invited the participants to express their opinions, opening the discussion to a lively debate.

\subsection{Step 4. Analysis of workshop findings}

During step 4, we analysed the completed questionnaires and the discussions that took place during the workshops. All group debates were transcribed and thematically coded, about 30 hours in all; the methodology—described in detail in Figureau et al. (2015) and similar to the approach used by Hasselman and Stoker (2017)—involved constructing a database, with records of specific statements by individual participants during a workshop, 
consisting of a few sentences of exact wording. When a statement was repeated during a workshop, only one record was entered in the database. We then grouped individual statements into six main categories, each comprising several sub-categories: (i) Preconditions related to general context (first component on Figure 1); (ii) Preconditions related to the capping process (second component of Figure 1); (iii) Principle stands; (iv) Advantages of groundwater trading, (v) Risks of market failure, and (vi) Options for improving the proposed instrument. Two of the authors repeated the analysis to check for potential interpretation bias. Finally, we used the database for calculating quotation frequencies in each sub-category of statements.

\section{CAP AND TRADE SCENARIO}

France has taken a firm step towards integrated water-resource management with its 1992 Water Law (Rinaudo, forthcoming), which introduced metering and licencing for water abstraction. The 2006 Water Law strengthened the legal framework for quantitative water-management issues (Rinaudo and Hérivaux, 2014; Montginoul et al., 2016). Hereafter, we describe the background to French groundwater policy, presenting the proposed cap and trade scenario and how it can be adapted to individual cases.

\subsection{Policy background}

The 2006 law imposed a cap on water use in basins with a structural groundwater deficit. In theory, the cap is designed to protect the good ecological status of groundwater-dependent ecosystems under normal climatic conditions, i.e. 4 years out of 5. The State attributes the capped volumes to the different economic sectors (cities, industries and agriculture). The volume allocated to agriculture is officially assigned to the newly formed Groundwater User Associations (GWUA), which are responsible for sharing the water among farmers. Under State supervision, GWUAs must develop their own rules for determining individual entitlements. When we organized the workshops in 2012-2013, the GWUAs had only just been established.

\subsection{Main components of the cap and trade scenario}

The main components of the cap and trade scenario discussed with French institutional stakeholders and farmers during the workshops are set out below.

It was assumed that by 2020 most of the conditions required for establishing groundwater markets would have been met. Groundwater is a limiting factor for agricultural production in many basins, which are de facto closed to new entrants; the cap is in place, and users have clear water entitlements defined for a 10-year period. 
The cap may be adjusted annually, depending on meteorological conditions and hydrological status. Individual water allocations are adjusted accordingly before the irrigation season. Although allocation rules may vary between GWUAs, most groundwater allocations are based on average historical use. In addition, the early signs of climate change announce an increasing water scarcity, especially during summer. Significant improvements in scientific understanding of local hydrogeology have removed much of the uncertainty (and controversy) about cap values, allowing more accurate assessment of the possible impact associated with changes in the spatial distribution of pumping. As the legal powers of GWUAs have been strengthened, they now can experiment with new allocation mechanisms, if equal treatment for all members is guaranteed. Several technological innovations have been widely adopted, such as smart meters and the use of remote sensing. This has helped resolving the problems of compliance and enforcement.

In 2035, water allocations will become tradable between farmers who are GWUA members. Until 2037 , farmers will only be able to trade their individual allocations on a temporary basis, for instance a season or a year. Permanent trading of water entitlements will be possible after 2037.

GWUAs play a key role in trade regulation. They register all transactions, publish sale- and purchase offers on their website, as well as a summary of trading activities (volumes sold and prices) at the end of the irrigation season. They verify the absence of third-party impact before approving a transaction. Water trading is only allowed before the irrigation season starts, and only between farmers in the same groundwater management unit (GMU), as defined by the GWUA. Groundwater entitlements remain subject to administrative authorization; at the end of their period of validity they can be adjusted, or even revoked, without compensation. The scenario thus introduces flexibility in groundwater allocation without modifying the foundations of French water policy.

\subsection{Adaptation to local hydrogeological characteristics}

We then adapted this scenario to fit the specific hydrogeological characteristics of each of the five selected groundwater basins. Our case studies broadly cover three types of aquifer. The first, illustrated by the Lyonnais aquifer, consists of three large alluvial systems characterized by high inertia. Given their very significant water reserves, they can easily buffer inter-annual fluctuations due to recharge (rainfall) or water abstraction by users. Consequently, the total abstraction limit can be relaxed, and the cap can be based on an average abstraction limit over a 5-year moving-average period. This allows users to carry over part of their water entitlement from one season to the next; we assumed a $20 \%$ carry-over in the Lyonnais aquifer scenario. 
The second type of aquifer is characterized by intermediate inertia. Based on observed groundwater levels at the beginning of the season, managers can make fairly reliable predictions about the volumes that can be pumped in the next six months, without putting dependent ecosystems at risk. Here, a yearly cap is set, and entitlements correspond to an annual pumping limit. If necessary, the cap may be reduced before the start of the season and individual water allocations readjusted accordingly. These assumptions were incorporated in the scenario discussed with stakeholders in the Tarn-et-Garonne plain and the Serre basin.

The third type of aquifer is characterized by low inertia. Here, it is difficult to predict the volume available during the cropping season as it depends on rainfall, and we assumed that a low value is set for the yearly cap. Similarly, the individual allocations granted to farmers reflect this cautious approach. Such uncertainty diminishes a few months into the growing season, and the available resource can be predicted with greater precision. Individual allocations can then be adjusted as a function of the available resource.

How the cap is defined has obvious implications for groundwater trading. In the high-inertia case, uncertainty is minimal because water can be purchased in advance and the volume traded can be fully guaranteed over a 5-year period. The second case is similar: the volume can only be guaranteed for the season, but it fluctuates from year to year. In both cases, we assumed that any trade in groundwater occurs before the start of the season. In the third case, farmers leasing water entitlements before sowing their crop do not know how much water they will be allocated during the season. Therefore, we proposed that a first round of trading could be conducted before the growing season. A second round would be optional if additional volumes are allocated later in the season.

We assumed that trade is restricted to existing groundwater management units (GMUs), which vary in size from 6,000 to 40,000 ha, depending on the hydrogeological nature of the aquifer. 
Author-produced version of the article published in Water Economics and Policy (2019)

The original publication is available at https://www.worldscientific.com/

https://doi.org/10.1142/S2382624X19500097

Table 2. Main differences in the five case studies concerning the cap and trade scenario

\begin{tabular}{|c|c|c|c|c|c|}
\hline & Lyonnais aquifer & $\begin{array}{l}\text { Tarn-et-Garonne } \\
\text { plain }\end{array}$ & Serre basin & Clain basin & Valence plain \\
\hline $\begin{array}{l}\text { GMU } \\
\text {. Number } \\
\text {. Average size (ha/GMU) } \\
\text {. Average number of irrigating } \\
\text { farms/GMU }\end{array}$ & $\begin{array}{c}3 \\
13,000 \\
107\end{array}$ & $\begin{array}{c}15 \\
6,000 \\
37\end{array}$ & $\begin{array}{c}1 \\
40,000 \\
95\end{array}$ & $\begin{array}{c}9 \\
35,000 \\
44\end{array}$ & $\begin{array}{c}5 \\
10,000 \\
25\end{array}$ \\
\hline $\begin{array}{l}\text { Cap } \\
. \% \text { decrease }(2013-20) \\
\text {. Type of cap }\end{array}$ & $\begin{array}{l}-20 \% \\
\text { Multi-year volume } \\
\text { (5 years })\end{array}$ & $\begin{array}{l}-20 \% \text { to }-80 \% \\
\text { Annual volume }\end{array}$ & $\begin{array}{c}0 \% \\
\text { Annual volume }\end{array}$ & $\begin{array}{l}\quad-50 \% \\
\text { Seasonal volume } \\
\text { (spring/summer) }\end{array}$ & $\begin{array}{l}-20 \% \text { in summer } \\
\text { Seasonal volume } \\
\text { (spring/summer) }\end{array}$ \\
\hline Individual entitlements & $\begin{array}{l}\text { Multi-year volume } \\
\text { (5 years) }\end{array}$ & \multicolumn{2}{|c|}{ Annual volume } & \multicolumn{2}{|c|}{ Seasonal volume (spring/summer) } \\
\hline Individual allocation & $\begin{array}{l}\text { No adjustment as a } \\
\text { function of the } \\
\text { piezometric level } \\
\text { (100\% entitlement) }\end{array}$ & \multicolumn{2}{|c|}{$\begin{array}{l}\text { Adjusted each year ( } \mathrm{x} \% \text { entitlement) before } \\
\text { the irrigation season as a function of the } \\
\text { piezometric levels }\end{array}$} & \multicolumn{2}{|c|}{$\begin{array}{l}\text { Adjusted each year (x\% entitlement) during } \\
2 \text { seasonal allocation sessions as a function } \\
\text { of the piezometric levels }\end{array}$} \\
\hline Trading calendar & $\begin{array}{l}\text { Annually or for } 5 \\
\text { years, before the } \\
\text { irrigation season }\end{array}$ & \multicolumn{2}{|c|}{$\begin{array}{l}\text { Year round, before the irrigation season } \\
\qquad(01 / 04)\end{array}$} & \multicolumn{2}{|c|}{$\begin{array}{l}\text { Year round, before each irrigation period } \\
\text { (before } 01 / 04 \text { for spring allocations, } 15- \\
20 / 06 \text { for summer allocations) }\end{array}$} \\
\hline
\end{tabular}

GMU = groundwater management units 


\section{Results}

\subsection{Overview}

Groundwater trading proved to be controversial. This was clear from the different case studies and participants' responses. On average, $45 \%$ of participants were against groundwater trading, while $43 \%$ supported the idea under certain conditions. Only 3\% expressed their full support (Fig. 2a). The level of opposition varied from 25 to 69\%, depending on the basins studied and the types of actors. Our tables and figures presenting the results obtained for each basin, rank the results from the highest mean opposition rate (Lyonnais aquifer: 61\%) to the lowest (Tarn-etGaronne plain: 38\%). Farmers and institutional actors expressed similar positions, apart from the Valence plain and Serre basin where institutional actors are more favourable to the market than farmers.

While half of the participants consider that a cap and trade policy is a plausible future option for water policy, only $23 \%$ consider it desirable; Figure $2 \mathrm{~b}$ reveals contrasting views between case studies and actors; farmers' groups and institutional stakeholders in the same basin may have differing views regarding both probability (the Lyonnais example) and desirability (Valence plain).

Overall, the participants expressed serious concerns about the prerequisites for groundwater trading, given the general context (22\% of statements) and the capping process (28\% of statements) (Figs. 3a, 3b; Table 3). Even if the preconditions are met, the workshop participants (farmers and institutional stakeholders alike) expressed far more concern about the potential risks associated with groundwater markets (24\% of statements) than interest in the advantages resulting from trade (4\%). 
Author-produced version of the article published in Water Economics and Policy (2019)

The original publication is available at https://www.worldscientific.com/

https://doi.org/10.1142/S2382624X19500097

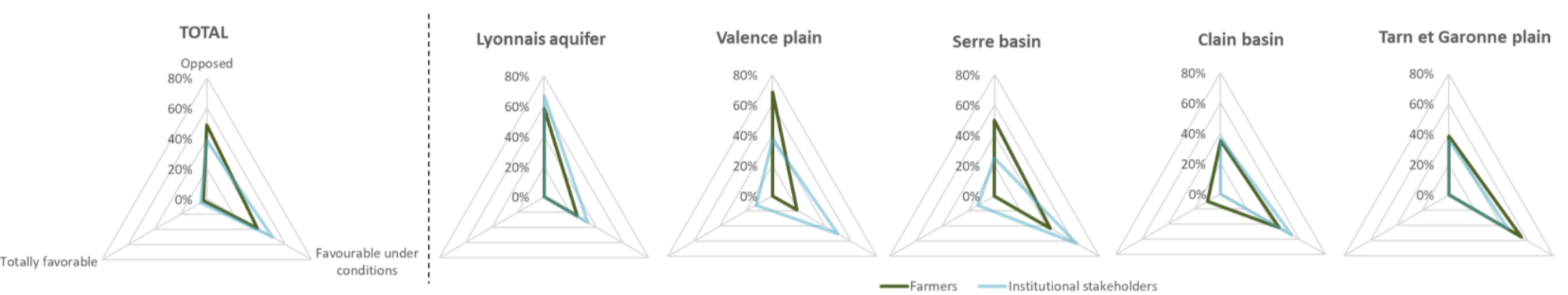

(a)

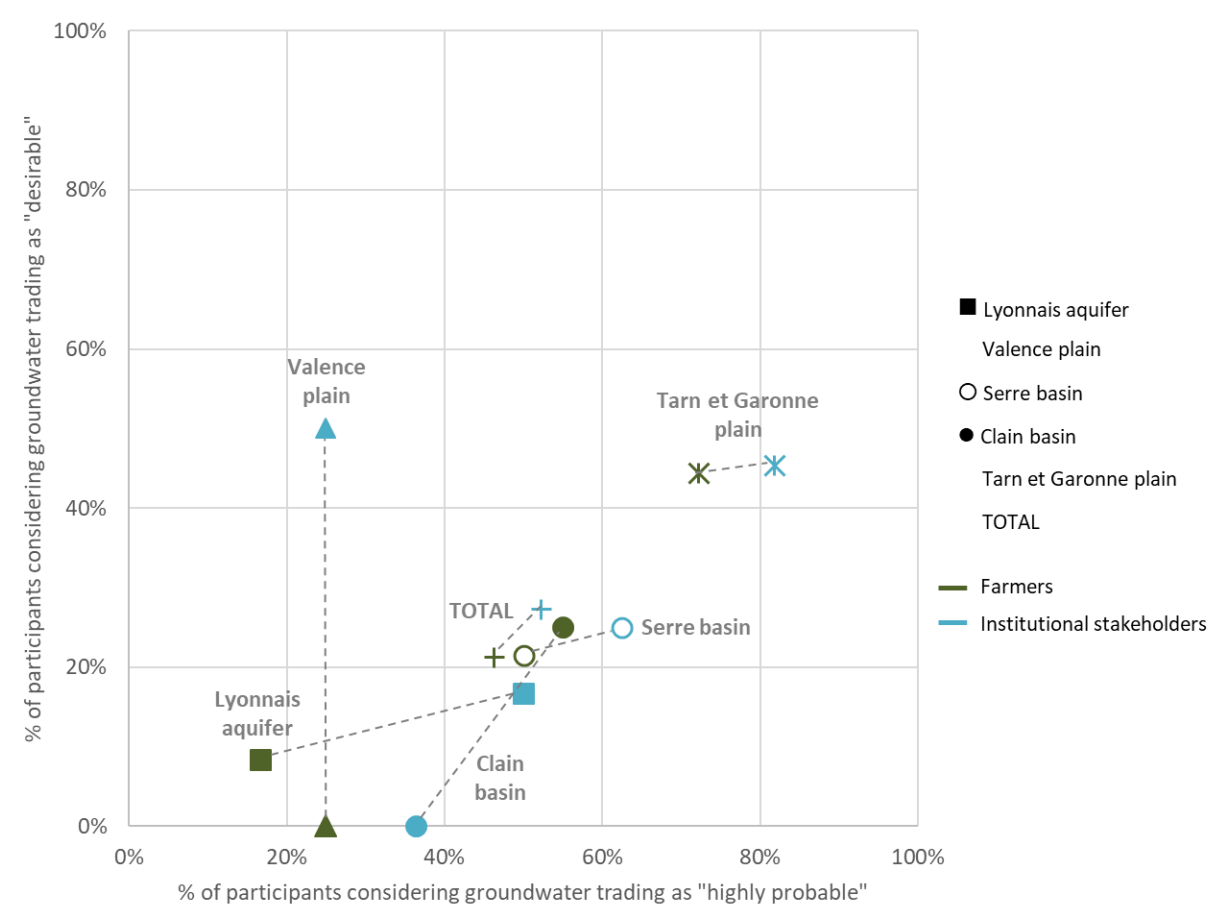

Fig. 2 (a) Principle stands regarding the possibility of buying and selling volumes of water, per basin and per stakeholder type (\% of participants), (b) probability and desirability of groundwater trading (the figure shows the \% of participants considering water trading as a highly probable ( $X$ axis) or highly desirable ( $Y$ axis) per basin and per stakeholder type) 
Author-produced version of the article published in Water Economics and Policy (2019)

The original publication is available at https://www.worldscientific.com/

https://doi.org/10.1142/S2382624X19500097

300
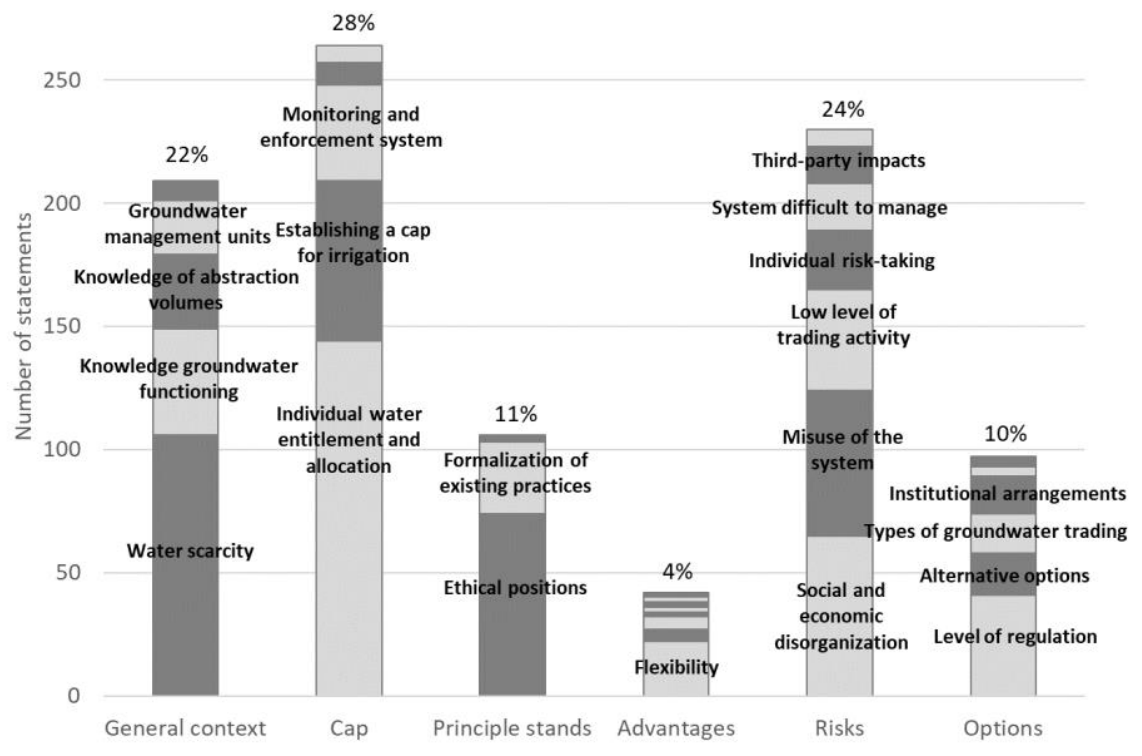

(a)

(b)

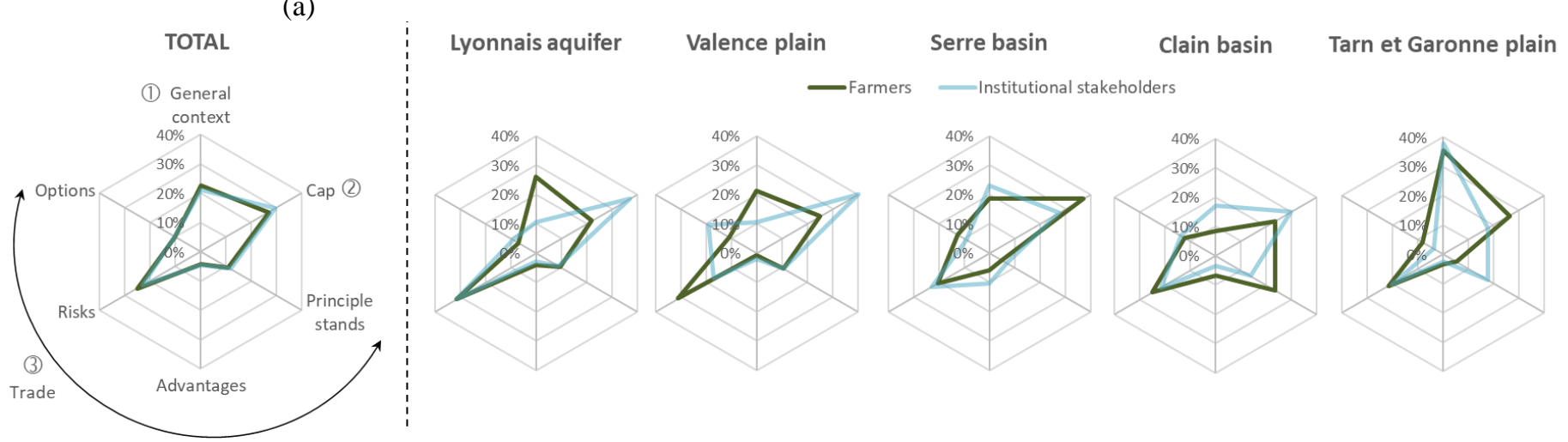

Fig. 3 (a) Number of statements quoted during the workshops per category (out of a total of 948 statements), (b) Proportion of statements quoted during the workshops per category and type of actors for each case study 


\subsection{Meeting the preconditions for trade is not for tomorrow}

At first glance, an economist may argue that French water management and policy frameworks are sufficiently mature for introducing groundwater trading in the agricultural sector. Water use has been capped in basins with a structural deficit, all water abstraction is declared, and water use is systematically metered. However, a closer look at the five case studies reveals that several problems regarding the preconditions for trading have yet to be resolved, particularly concerning the first two components of the cap and trade policy scenario (General context, Cap, Fig. 1). The results also highlight significant differences between the basins, as shown in terms of the distribution of the opinions expressed (Table 3). These differences are linked to the contrasting situations in the basins, such as water scarcity and the history of existing quantitative management systems. It also shows that some basins may not be ready for the introduction of groundwater trading.

\subsubsection{General context}

The key elements related to the general context are mentioned in $22 \%$ of the statements; $11 \%$ of participants discussed the assumption that water scarcity will increase in the future. This was the case in several basins depending on the situation, such as in the Tarn-et-Garonne and Valence where surface water can be used as an alternative resource, in the Lyonnais and Serre where restrictions in groundwater use for irrigation are still rare, or in the Tarn-et-Garonne and Serre where hydrogeological modelling results remain controversial and have yet to be fully accepted. In some basins, the limited groundwater knowledge created problems (5\% of statements). Some participants thought that acquiring the detailed geological and hydrological data described in the scenario would take decades. Setting up appropriate monitoring networks will effectively take years, as will subsequent data collection to allow statistical analyses.

Therefore, participants considered that water entitlements should not be made tradable before we have a better understanding of geological and hydrological issues. Until then, such trade might create insoluble political problems, particularly in the event of having to return to sustainable pumping levels. Moreover, groundwater resources are invisible and, in the case of high inertia (Lyonnais aquifer), they require long-term management. This can be difficult for users to grasp. Some users still disagree with the assumption that water is scarce, and they refuse to reduce their allocation in response to environmental concerns. In the two basins with the greatest opposition to groundwater trading (Lyonnais aquifer and Valence plain), stakeholders can have very different perceptions of water scarcity, farmers discussing the issue twice as much as institutional stakeholders, which may 
reflect different levels of knowledge. These different perceptions suggest that there is a need for creating room for dialogue between the different actors in each basin, to facilitate the exchange of viewpoints.

Table 3. Statements quoted by workshop participants per category and case study

\begin{tabular}{|c|c|c|c|c|c|c|c|}
\hline \multirow[b]{2}{*}{ Statement category } & \multicolumn{6}{|c|}{ Number of statements per category } & \multirow{2}{*}{$\begin{array}{l}\text { Number of } \\
\text { workshops }^{\mathrm{a}}\end{array}$} \\
\hline & Total & $\begin{array}{c}\text { Lyon- } \\
\text { nais }\end{array}$ & Valence & Serre & Clain & $\begin{array}{c}\text { Tarn } \\
\text { Garonne }\end{array}$ & \\
\hline (1) GENERAL CONTEXT & 209 & 26 & 27 & 39 & 26 & 91 & 16 \\
\hline Water scarcity & 106 & 12 & 16 & 17 & 12 & 49 & 16 \\
\hline Knowledge groundwater functioning & 43 & 3 & 3 & 13 & 6 & 18 & 11 \\
\hline Knowledge of abstraction volumes & 30 & 5 & 2 & 3 & 7 & 13 & 11 \\
\hline Groundwater management units & 22 & 4 & 5 & 6 & 0 & 7 & 8 \\
\hline Heterogeneity of farming systems & 8 & 2 & 1 & 0 & 1 & 4 & 5 \\
\hline (2) CAP & 264 & 41 & 45 & 62 & 57 & 59 & 16 \\
\hline $\begin{array}{l}\text { Individual water entitlement and } \\
\text { allocation }\end{array}$ & 144 & 17 & 12 & 39 & 37 & 39 & 16 \\
\hline Establishing a cap for irrigation & 65 & 9 & 30 & 9 & 4 & 13 & 15 \\
\hline Monitoring and enforcement system & 39 & 11 & 2 & 8 & 12 & 6 & 13 \\
\hline Transparency and information & 9 & 2 & 1 & 4 & 2 & 0 & 4 \\
\hline Other & 7 & 2 & 0 & 2 & 2 & 1 & 6 \\
\hline (3) TRADE & 475 & 73 & 78 & 88 & 135 & 101 & 16 \\
\hline Principle stands & 106 & 13 & 16 & 11 & 43 & 23 & 15 \\
\hline Ethical positions & 74 & 13 & 16 & 8 & 26 & 11 & 15 \\
\hline Formalization of existing practices & 29 & 0 & 0 & 1 & 17 & 11 & 7 \\
\hline Other & 3 & 0 & 0 & 2 & 0 & 1 & 2 \\
\hline Advantages & 42 & 5 & 2 & 15 & 12 & 8 & 13 \\
\hline Flexibility & 22 & 3 & 0 & 10 & 7 & 2 & 8 \\
\hline Incentive for water savings & 5 & 0 & 1 & 0 & 0 & 4 & 4 \\
\hline Increase in agricultural production & 5 & 0 & 1 & 0 & 4 & 0 & 2 \\
\hline Other & 2 & 0 & 0 & 0 & 1 & 1 & 2 \\
\hline Self-regulated system & 2 & 0 & 0 & 1 & 0 & 1 & 2 \\
\hline Technical efficacy of irrigating water & 2 & 0 & 0 & 2 & 0 & 0 & 1 \\
\hline Efficiency of irrigation & 2 & 2 & 0 & 0 & 0 & 0 & 1 \\
\hline Environmental protection & 2 & 0 & 0 & 2 & 0 & 0 & 1 \\
\hline Risks of market failure & 230 & 44 & 40 & 41 & 52 & 53 & 16 \\
\hline Social and economic disorganization & 65 & 11 & 12 & 8 & 25 & 9 & 14 \\
\hline Misuse of the system & 59 & 17 & 10 & 5 & 3 & 24 & 14 \\
\hline Low level of trading activity & 41 & 7 & 6 & 17 & 5 & 6 & 13 \\
\hline Individual risk-taking for farmer & 24 & 3 & 7 & 4 & 2 & 8 & 12 \\
\hline System difficult to manage & 19 & 2 & 3 & 5 & 6 & 3 & 10 \\
\hline Third-party impacts & 15 & 4 & 1 & 2 & 8 & 0 & 6 \\
\hline Other & 7 & 0 & 1 & 0 & 3 & 3 & 4 \\
\hline Options & 97 & 11 & 20 & 21 & 28 & 17 & 14 \\
\hline Level of regulation & 41 & 7 & 5 & 15 & 14 & 0 & 9 \\
\hline Alternative options & 17 & 2 & 5 & 4 & 4 & 2 & 9 \\
\hline Types of groundwater trading & 16 & 1 & 0 & 1 & 7 & 7 & 7 \\
\hline Institutional arrangements & 15 & 1 & 7 & 1 & 1 & 5 & 9 \\
\hline Enable entry of new irrigators & 4 & 0 & 2 & 0 & 2 & 0 & 4 \\
\hline Other & 4 & 0 & 1 & 0 & 0 & 3 & 2 \\
\hline TOTAL & 948 & 140 & 150 & 189 & 218 & 251 & 16 \\
\hline
\end{tabular}

a Number of workshops (out of 16) where the statement was quoted at least once. 


\subsubsection{The capping process}

The capping process that came into force with the 2006 Water Law was a controversial issue in most of our case studies $(28 \%$ of statements).

In basins where groundwater-management schemes were only recently introduced, the main issue is linked to the cap on irrigation (7\% of statements); there, users are just starting to grasp the basic principles of quantitative management. Some participants were against future cap reductions to meet environmental constraints. The strongest opposition to capping was expressed in the Valence basin, where farmers have not yet experienced restrictions (20\% of statements), but no specific opposition was reported in basins where capping has existed for several years, such as the Clain basin where water use has been capped since 1994.

Concerning the capping volume, most participants agreed that caps should be set for each groundwater management unit, but they also anticipate that this may pose practical and technical problems. Assessing the volume is likely to be controversial at a local level. Participants were positive about the proposal to adjust the cap annually based on observed groundwater and meteorological conditions. However, farmers argued that such adjustments should be announced before they decide on their cropping plan. This is long before the announcement date proposed in the scenario, which date will inevitably be the result of a trade-off between environmental and economic concerns.

There was no consensus about individual water entitlements and allocations (15\% of statements). Depending upon the type of cropping system, farmers highlighted different factors that hinder establishing a universal definition for individual water entitlements, such as their duration, or the timetable for adjusting annual water allocations. Many farmers were concerned by the proposed 10-year validity period for water entitlements. Those who cultivate perennial crops (Tarn-et-Garonne and Valence plains) considered it was too short given the return period for their investments (15 years minimum for orchards), but farmers growing annual crops (Serre and Clain basins) argued that water entitlements should be redistributed each year to adjust for crop changes. They suggested that, depending on the cropping system, the proposed calendar for adjusting annual water allocations might be unsuitable, and should be carefully adapted to the constraints faced by different farmers if they were to accept it. In the Serre basin, for example, farmers grow vegetables under contract with agri-food companies that impose strict specifications, especially for the supply of irrigation water. It is inconceivable for these farmers to make a commitment to an industrial company unless they know how much water will be allocated to them.

The legitimacy of initial water allocations, commonly based on historical use, is problematic as well. Some participants challenged our assumption that entitlements could be based on historical water-use records. 
They argued that individual allocations based on previous history would freeze the-apparently unfair and inefficient - allocation system now used. It would also be detrimental to farmers who invested in water-saving technology, instead of rewarding their efforts. However, there was no agreement on the criteria that should be used for calculating the initial allocation, to ensure that it would be fair and efficient.

Finally, the participants discussed the role allocated to the GWUAs in our scenario, agreeing that they should play a greater role when it comes to defining water-allocation rules. However, there was no consensus on the respective roles of users and the State in terms of monitoring and enforcement. In general, government agencies like to transfer certain responsibilities to farmers, such as monitoring water use, detecting illegal abstraction, or even sanctioning deviant behaviour, by excluding the defaulter from GWUA membership and thus cancelling his right to pump. But farmers are clearly reluctant to assume such responsibilities, in particular sanctioning, which they consider to be a State mission.

\subsection{Anticipated negative effects and the demand for regulations}

Anticipated risks may heighten opposition to groundwater trading; they represent $24 \%$ of the concerns raised during the workshops, and over $30 \%$ for the two basins with the highest opposition rates. Participants did not expect the proposed groundwater market to function as predicted in theory. Some (7\% of statements) feared that water trading could disrupt the social and economic equilibrium of entire regions. The perceived risk is that the ownership of water rights, with a high marginal value, will be concentrated in the hands of a few large farmers. Private firms outside the agricultural sector could also purchase agricultural water rights; this might disrupt agriculture at a regional level, causing the possible collapse of entire value chains and the economic decline of certain rural areas. Some participants were also concerned that water trading would increase competition between farmers, reduce cooperative initiatives, exacerbate social fragmentation, and erode rural solidarity. Some (6\% of statements) were also concerned that the trading system might deviate from its primary objectives, the risk being that some farmers could gradually become water traders rather than agricultural producers. Beneficiaries of large water allocations might start speculating, through withholding water rights from productive use to create artificial scarcity on the market and raise prices.

Some participants thus proposed that groundwater trading should be subject to strict regulations, for example with controls over time, geographic scale, tradable volumes and even prices. They strongly defended the idea that trade should only occur before the growing season and be prohibited once this is underway. Some participants pointed out that strict regulations would significantly restrict trade opportunities. Overall, these 
comments reveal an extreme suspicion about groundwater markets, which was further illustrated by frequent references to the stock option market.

\subsection{Low levels of trading are expected}

The case studies also raised questions about the potential benefits of groundwater trading. Some participants stressed that trading would remain very limited (4\% of statements), especially in areas where GMUs are small and farming systems are little diversified. While two thirds of farmers declared that they would probably trade water if the proposed scenario was implemented, only $5 \%$ declared that they would do so regularly. Over $60 \%$ thought that the traded volumes would represent less than $10 \%$ of the total allocated volume (Fig. 4).
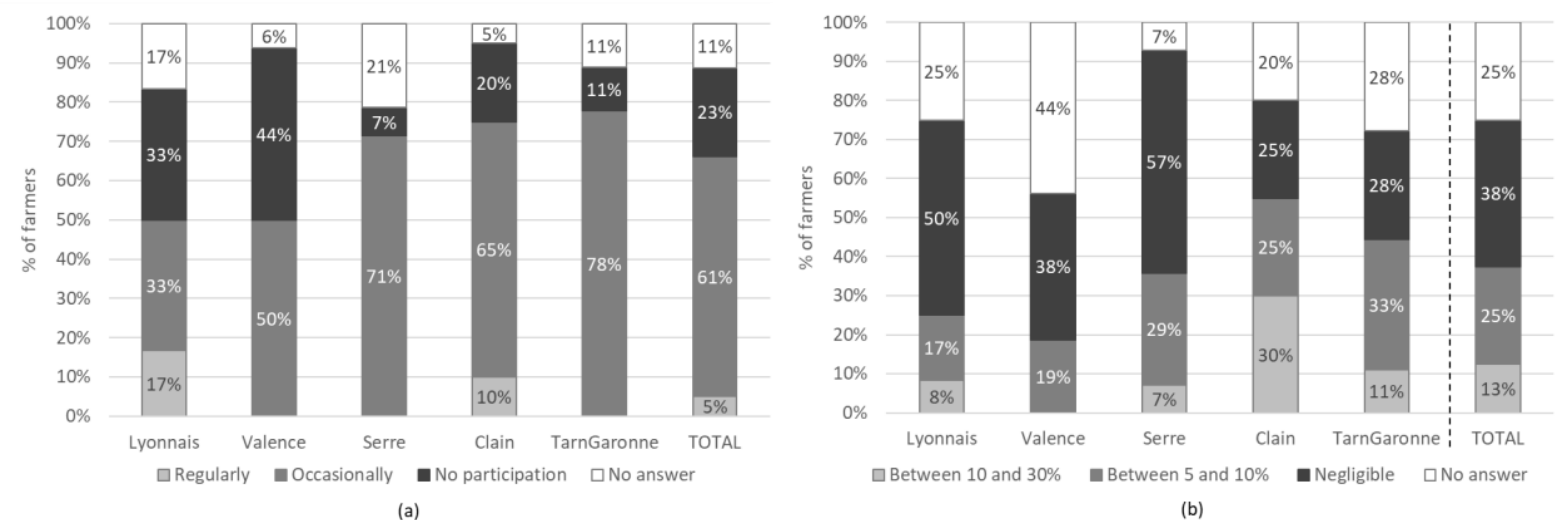

(b)

Fig. 4 Anticipated trading activity per case study: (a) percentage of farmers declaring they would participate occasionally or regularly and (b) estimation of the global percentage of allocated volume that would be traded if the groundwater market

scheme was established.

These findings can be linked to the fact that only a minority of participants expressed an opinion about the potential advantages of groundwater trading ( $4 \%$ of statements). Some recognized that groundwater trading could improve flexibility, by allowing them to reduce irrigation without losing their water entitlement-in the case of illness or prior to retirement - or increase irrigation to boost crop yields at the end of the season if water is available. A minority declared that groundwater trading might provide an incentive for using more efficient irrigation techniques. This could increase total agricultural production at the basin scale, if farmers are encouraged to use dormant volumes. 


\section{DiscUSSION}

The results presented above are consistent with the recent literature on water markets. They confirmed that, whether water trading will be a viable tool for ensuring sustainable groundwater management, will depend on a host of basin-specific factors (Wheeler et al., 2017; Babbit et al., 2017; Green Nylen et al., 2017).

Our study confirmed that shifting from a regulatory to a market-based water governance worried many water users and stakeholders, even when carefully adapting the cap and trade scenario to local conditions. The institutional arrangements we proposed to French stakeholders incorporate many safeguards against the risk of market failure. The factors explaining this rejection of cap and trade were globally the same as those reported in other papers analysing the limits of market-based forms of water governance (Galaz, 2004; Gianocarro et al., 2013; Hernandez-Mora and del Moral, 2015; Hasselman and Stoker, 2017; Holley and Sinclair, 2018). We review those factors below.

The views expressed by French stakeholders that preconditions for establishing cap and trade scenarios are not met, echoed findings in other countries. Several authors (e.g. Boyd and Brumley, 2004; Skurray et al., 2012) identified a good understanding of the groundwater resource and its functioning as one of the key scientific challenges for establishing groundwater trading.

Our analysis also showed that part of the opposition expressed by French stakeholders concerns the capping process. Both the cap setting and the initial allocation of water-use rights are major challenges that, if not properly addressed, can impede the establishment of a water market (McAllister, 2009; Holley and Sinclair, 2018). The capping process may be at different stages of development, and insufficiently mature for introducing water trading (Easter et al., 1999). Another major concern was the initial allocation of individual water-use rights where they do not pre-exist. Stakeholders were particularly concerned by—and had diverging views on—how water-use rights should be defined and initially allocated among users (Syme and Nancarrow, 1997; 2006; Nancarrow et al., 1998; Rinaudo et al., 2016b). In over-allocated basins, users may advocate different rules for reducing allocations or entitlements, such as across-the-board reduction, or cancellation of dormant rights. This process raises a debate that focuses on the issue of distributive justice (Rinaudo et al., 2016b). Poor acceptance of this initial process will increase the risk of conflicts associated to trading. Moreover, the monitoring of groundwater abstraction remains a weak link in France (Montginoul et al., forthcoming) and elsewhere (Zhang, 2007, in China; Holley and Sinclair, 2018, for Australia). Compliance problems could increase with water trading as this increases financial incentives for disobeying the rules. Holley and Sinclair's (2018) conclusion, which could apply to the French context, is that 
"if caps are exceeded due to illegal water extraction, if [...] tradable water rights are not adhered to, and if stakeholders lack confidence that there is an equitable sharing of water, the entire edifice of the market can be undermined".

Once water use is capped and initial allocations are set, making the water-use rights tradable raises further significant opposition. In France and elsewhere, water users may contest the legitimacy of market-based forms of governance on ethical grounds. Because market mechanisms emphasize individual values and stimulate competition, they can erode community spirit and crowd out more ethical and moral behaviour (Holley and Sinclair, 2018). Water markets are also contested by those who think that they encourage gaming — and possibly fraudulent — behaviour, but also may favour people making money by managing risk over those who use water for producing goods (Hasselman and Stoker, 2017; Holley and Sinclair, 2018). This reflects a broader concern that our society is moving from a production economy to a speculation one (Sandel, 2013).

Another claim of French water-market doubters is that the market will benefit wealthier users and increase inequality. This is echoed in certain Australian studies based on qualitative or quantitative surveys; for instance, Wheeler et al. (2014) showed that early market adopters have higher education and income levels. The fear expressed by some French stakeholders, that water trading beyond the region may threaten business and employment, is also known from studies elsewhere; Connell (2015), for instance, reported that in the Australian Murray Darling basin, water sales outside local communities are perceived as a loss of control over the future. He noted that water trading has disrupted social cohesion between irrigators and their communities, creating stresses where previously there was a strong sense of shared destiny.

During our workshops, however, there were few discussions about spatial externalities despite the fact that the spatial reallocation of groundwater volumes is a major issue in the literature on groundwater trading as it can change the distribution and magnitude of pumping externalities (Howe, 2002; Brozovic et al., 2010; Skurray et al., 2012; Kuwayama and Brozovic, 2013).

Concerning the limited potential economic benefits generated by groundwater trading, the concerns expressed by French farmers again confirm findings reported in the literature. In Australia, where trade is restricted within a groundwater management unit, mostly to prevent environmental externalities, few transactions occur and the market remains quite thin (GHD et al., 2011; Skurray et al., 2012; Holley and Sinclair, 2018); this is supported by the fact that transactions in the states of NSW and Victoria represent only $1 \%$ of groundwater allocation. At the national level, $75 \%$ of Australian groundwater trade occurs in three major alluvial aquifers, characterized by a high number of licences and large volumes, high water demand and low availability (GHD et al., 2011). 
More generally, the latest French agricultural census in 2010 showed that irrigation concerned only $5.8 \%$ of agricultural land (Loubier et al., 2013). Farmers often use irrigation simply as an insurance for dry years. Trading is only expected to occur in large homogeneous groundwater units and areas with highly diversified farming systems, but France's implementation of the European Water Framework Directive has led to the identification of over 550 shallow groundwater bodies nation-wide. In areas where over-pumping is a problem, the cap should be defined at GMU scale, guaranteeing minimum water flow in connected surface-water systems. At this scale, the number and diversity of farming systems is expected to be low.

Overall, stakeholders' fears are understandable given the scope of a reform that would simultaneously reduce total water use by setting abstraction limits, define new water use rights, allocate them among users, and make them tradable. However, as illustrated by Wheeler et al. (2014), market adoption is a relatively long process. It takes time for all users to fully understand the rules and potential benefits of water trading. It also takes time for institutions to adapt and reduce transaction costs. Recognizing the length of this process is essential. Thus, we fully support Babbitt's advice to Californian Groundwater Sustainability Agencies: “Because any agency is unlikely to design the rules perfectly at the outset, it might be prudent to start a trading program with lease only - no permanent transfers. [...] Testing trading rules with a handful of single year transfers can help Groundwater Sustainability Agencies to learn, better understand the incentives and effects of their rules, and trouble-shoot any issues that arise". This process is likely to be costly, given the depth of the institutional reforms that are needed.

\section{Conclusions}

This paper contributes to the future evolution of the French water policy, highlighting the key challenges of introducing groundwater trading in the agricultural sector. Our results concern five groundwater basins, showing that $50 \%$ of farmers and $40 \%$ of institutional stakeholders are opposed to groundwater trading for various ethical, economic and technical reasons. First, we do not yet meet the preconditions for introducing groundwater markets (water scarcity, sufficient knowledge on groundwater), and the capping process remains controversial in many French basins. Second, major negative effects are anticipated when developing a groundwater market. Regulatory measures to limit such negative impact may, in turn, hinder trading and call its very existence into question.

Despite these reservations, our results suggest that, with time, there may be scope for developing groundwater markets that are compatible with the French water policy context. If groundwater trading is envisaged, the market regulation mechanisms should be designed at a local scale, within GWUAs. This would ensure that 
specific hydrogeological features, the local groundwater management history, and local farming constraints are considered.

Hydrogeological characteristics necessarily influence the way a cap is defined, allowing for flexibility when it comes to adjusting annual abstraction volumes as a function of aquifer inertia. Existing quantitative management schemes, however, may not be ready to support groundwater trading, and it may be necessary to adapt individual entitlements and allocations to suit the needs of specific cropping systems.

In line with the subsidiarity principle of French water laws, national legislation would offer a framework for developing water trading, without imposing universal groundwater-trading rules and market regulations. It is likely that stakeholders in some pilot groundwater basins may start introducing trading systems, adopting a cautious approach with numerous trade restrictions. Over time, trading may be abandoned in some basins because of undesirable negative effects, or the small number of transactions. But,once the trading process has been demystified and trust develops among users, trading restrictions may be loosened in other basins (Babbitt et al., 2017).

Other decentralized management approaches exist for providing flexibility and increasing efficiency in allocation. Some of these options, which rely on setting up water-user associations and decentralized selfmanagement by users, are a clear alternative to the dichotomy between State and Market. This option is discussed by Figureau et al. (2015) and Holley and Sinclair (2014), among others.

From a methodological perspective, our study should help in designing and evaluating groundwater market instruments with local actors, and at groundwater-basin scale. It underlines the importance of involving both local farmers and institutional stakeholders in discussions on market mechanisms, ensuring that their different views are equally considered. Organizing workshops that allow the different stakeholders to express their opinions is a first step in a broader participatory process. The second step is to encourage discussion, to help the actors create a shared vision of groundwater management. As suggested by Babbitt et al. (2017), this may help reducing potential blockages due to misunderstandings.

More generally, the proposed participatory approach should encourage the GWUAs to consider the diverse views of users when they design future rules for managing groundwater allocation. Supporting such a participatory process requires an interdisciplinary approach to water markets, combining concepts and analytical frameworks from not only economics and groundwater science, but also from sociology, law, institutional theory and moral philosophy (Gomez-Baggethun and Muradian, 2015). 


\section{References}

Babbitt C, M Hall, A Hayden, AL Garcia Briones, R Young and N Brozović (2017). Groundwater Trading as a Tool for Implementing California’s Sustainable Groundwater Management Act. Environmental Defense Fund. http://Edf.org/WaterTrading [18 June 2019]

Bauer, CJ (1997). Bringing water markets down to earth: The political economy of water rights in Chile, 19761995. World Development, 25, 639-656.

Bauer, CJ (2012). Against the current: privatization, water markets, and the state in Chile. In Natural Resource Management and Policy, Vol. 14. New York: Springer US.

Boyd, T and J Brumley (2004). Optimising sustainable use of groundwater: a challenge for science and water markets. 1st International Conference on Sustainability Engineering and Science, 6-9 July 2004, Auckland, New Zealand.

Brozovic, N, DL Sunding and D Zilberman (2010). On the spatial nature of the groundwater pumping externality. Resource and Energy Economics, 32, 154-164.

Brozović, N and R Young (2014). Design and implementation of markets for groundwater pumping rights. In Water Markets for the 21st Century, Easter, K, and Q Huang (eds), Global Issues in Water Policy, Vol. 11, pp. 283-303. Dordrecht: Springer.

Connel, D (2015). Irrigation, water markets and sustainability in Australia's Murray-Darling basin. Agriculture and Agricultural Science Procedia, 4, 133-139.

Easter, KW, MW Rosegrant and A Dinar (1999). Formal and informal markets for water: institutions, performance, and constraints. The World Bank Research Observer, 14, 99-116.

Easter, KW and Q Huang (eds.) (2014). Water markets for the 21st Century: What have we learned? Dordrecht: Springer.

Figureau, AG, M Montginoul and JD Rinaudo (2015). Policy instruments for decentralized management of agricultural groundwater abstraction: A participatory evaluation. Ecological Economics 119, 147-157.

Galaz, V (2004). Stealing from the poor? Game theory and the politics of water markets in Chile. Environmental Politics, 13, 414-437.

GHD, Hamstead Consulting and V O'Keefe (2011). A framework for managing and developing groundwater trading. Waterlines Report Series No 52. National Water Commission of the Australian Government, Canberra. 
Giannoccaro, G, V Pedraza and J Berbel (2013). Analysis of stakeholders' attitudes towards water markets in Southern Spain. Water, 5, 1517-1532.

Giannoccaro, G, M Castillo and J Berbel (2016). Factors influencing farmers' willingness to participate in water allocation trading. A case study in southern Spain. Spanish Journal of Agricultural Research, 14.

Gómez-Baggethun, E and R Muradian (2015). In markets we trust? Setting the boundaries of market-based instruments in ecosystem services governance. Ecological Economics, 117, 217-224.

Grafton, RQ, G Libecap, S McGlennon, C Landry and B O'Brien (2011). Integrated assessment of water markets: a cross-country comparison. Review of Environmental Economics and Policy, 5, 219-239.

Green Nylen N, M Kiparsky, K Archer, K Schnier and H Doremus (2017). Trading sustainably: critical considerations for local groundwater markets under the sustainable groundwater management act. Wheeler Water Institute, Center for Law, Energy \& the Environment. UC Berkeley School of Law.

Hamilton, S and A Smithson (2010). Addressing the challenges of groundwater trading in NSW, Australian National Groundwater Conference, 31 October - 4 November 2010, National Convention Centre, Canberra.

Hasselman, L and G Stoker (2017). Market-based governance and water management: the limits to economic rationalism in public policy. Policy Studies, 38, 502-517.

Heinmiller, BT (2007). The Politics of" Cap and Trade" Policies. Natural Resources Journal, 47, 445-467.

Hernández-Mora, N and L Del Moral (2015). Developing markets for water reallocation: Revisiting the experience of Spanish water mercantilización. Geoforum, 62, 143-155.

Holley, C and D Sinclair (2014). A new water policy option for Australia? Collaborative water governance, compliance and enforcement and audited self-management. Australasian Journal of Natural Resources Law and Policy, 17, 189-216.

Holley, C and D Sinclair (2018). Water Markets and Regulation: Implementation, Successes and Limitations. In Reforming Water Law and Governance: From Stagnation to Innovation in Australia, Holley C and D Sinclair (eds), pp. 141-168. Singapore: Springer.

Howe, CW (2002). Policy issues and institutional impediments in the management of groundwater: lessons from case studies. Environment and Development Economics, 7, 625-641. 
Kuwayama, Y and N Brozović (2013). The regulation of a spatially heterogeneous externality: Tradable groundwater permits to protect streams. Journal of Environmental Economics and Management, 66, 364382.

Lawson, S, A Buckingham, M Hamstead and V O'Keefe (2010). Overcoming impediments to groundwater trading in Australia, Australian National Groundwater Conference, 31 October - 4 November 2010, National Convention Centre, Canberra.

Livingston, ML (1995). Designing water institutions: market failures and institutional response. Water Resources Management, 9, 203-220.

Loubier, S, M Campardon and S Morardet (2013). L'irrigation diminue-t-elle en France ? Premiers enseignements du recensement agricole de 2010. Sciences Eaux \& Territoires, 11, 12-19.

Lumbroso, DM, C Twigger-Ross, J Raffensperger, JJ Harou, M Silcock and AJK Thompson (2014). Stakeholders’ responses to the use of innovative water trading systems in East Anglia, England. Water Resources Management, 28, 2677-2694.

McAllister, LK (2009). The overallocation problem in cap-and-trade: moving toward stringency. Columbia. Journal of Environmental Law, 34, 395-445.

Montginoul, M, JD Rinaudo, N Brozović and G Donoso (2016). Controlling groundwater exploitation through economic instruments: Current practices, challenges and innovative approaches. In Integrated Groundwater Management, Jakeman AJ, O Barreteau, RJ Hunt, JD Rinaudo and A Ross (eds), pp. 551581. Cham: Springer.

Montginoul, M, JD Rinaudo and C Alcouffe. Compliance and enforcement: the Achilles heel of French water policy. In Sustainable groundwater management: a comparative analysis of French and Australian policies and implications to other countries, to appear in Global issues in Water policy series. Springer International Publishing.

Nancarrow BE, JA McCreddin and GJ Syme (1998). Developing fair processes for the reallocation of groundwater for long term sustainability in the Namoi Valley. Consultancy report 98-40. Australian Research Center for Water and Society, CSIRO Land and Water, Canberra

OECD (2015). Water Resources Allocation: Sharing Risks and Opportunities, OECD Studies on Water, OECD Publishing, Paris.

Rahimova N, H Hesseln, and P Silven (2016). Factors affecting water market acceptance: A case study of stakeholders in southern Alberta, Canada. The Canadian Geographer, 60, 245-258. 
Rey, D, A Garrido, and J Calatrava (2014). The Water markets in Spain: moving towards 21st Century mechanisms and approaches with 20th Century regulations. In: Water Markets for the 21st. Century: What Have We Learned, Easter KW and Q Huang (eds), pp. 127-147, Dordrecht: Springer Netherlands.

Rinaudo, JD and P Garin (2005). The benefits of combining lay and expert knowledge for water management planning at the watershed level. Water Policy, 7, 279-293.

Rinaudo, JD, M Montginoul, M Varanda and S Bento (2012). Envisioning innovative groundwater regulation policies through scenario workshops in France and Portugal, Irrigation and Drainage, 61, 65-74.

Rinaudo, JD and C Hérivaux (2014). Quels instruments pour une gestion collective des prélèvements individuels pour l'irrigation ? Onema: Paris.

Rinaudo, JD, J Calatrava and M Vernier de Byan (2016a). Tradable water saving certificates to improve urban water use efficiency: an ex-ante evaluation in a French case study. Australian Journal of Agricultural and Resource Economics, 60, 422-441.

Rinaudo, JD, C Moreau and P Garin (2016b). Social justice and groundwater allocation in agriculture: A French case study. In Integrated Groundwater Management, Jakeman AJ, O Barreteau, RJ Hunt, JD Rinaudo and A Ross (eds), pp. 273-293. Cham: Springer.

Rinaudo, JD. The evolution of groundwater management policy in France. In Sustainable groundwater management: a comparative analysis of French and Australian Policies and implication to other countries, Rinaudo, JD, C Holley, M Montginoul and S Barnett (eds), to appear in Global issues in Water policy series. Springer International Publishing.

Rosegrant, MW and HP Binswanger (1994). Markets in tradable water rights: potential for efficiency gains in developing country water resource allocation, World Development, 22, 1613-1625.

Sandel, MJ (2013). The moral economy of speculation: Gambling, finance, and the common good. The Tanner Lectures on Human Values. Delivered at University of Utah February 272013.

Skurray, JH, EJ Roberts and DJ Pannell (2012). Hydrological challenges to groundwater trading: Lessons from south-west Western Australia. Journal of Hydrology, 412-413, 256-268.

Skurray, JH, R Pandit and DJ Pannell (2013). Institutional impediments to groundwater trading: the case of the Gnangara groundwater system of Western Australia. Journal of environmental planning and management, 56, 1046-1072. 
Strosser, P and M Montginoul (2001). Vers des marchés de l'eau en France ? Quelques éléments de réflexion. Annales des Mines, 23, 13-31.

Syme, GJ and BE Nancarrow, (1997). The determinants of perceptions of fairness in the allocation of water to multiple uses. Water Resources Research, 33, 2143-2152.

Syme, GJ and BE Nancarrow, (2006). Achieving sustainability in water reform: A Western Australia case study. Water International, 31, 23-30.

Thobani, M (1997). Formal water markets: why, when, and how to introduce tradable water rights. The World Bank Research Observer, 12, 161-179.

Thompson, CL, RJ Supalla, DL Martin and BP McMullen (2009). Evidence supporting Cap and Trade as a groundwater policy option for reducing irrigation consumptive use. Journal of the American Water Resources Association, 45, 1508-1518.

Tisdell, JG and JR Ward (2003). Attitudes toward water markets: an Australian case study. Society \& Natural Resources, 16, 61-75.

Wheeler, S, A Loch, A Zuo and H Bjornlund (2014). Reviewing the adoption and impact of water markets in the Murray-Darling Basin, Australia. Journal of Hydrology, 518, 28-41.

Wheeler, S, A Loch, L Crase, M Young and Q Grafton (2017). Developing a water market readiness assessment framework. Journal of Hydrology, 552, 807-820.

Wheeler, SA, K Schoengold and H Bjornlund (2016). Lessons to be learned from groundwater - Trading in Australia and the United States. In Integrated Groundwater Management, Jakeman AJ, O Barreteau, RJ Hunt, JD Rinaudo and A Ross (eds), pp 493-517. Cham: Springer.

World Bank (1994). Water Resources Management. A World Bank policy paper. Washington, DC: The World Bank.

Young, MD (2014). Designing water abstraction regimes for an ever-changing and ever-varying future. Agricultural Water Management, 145, 32-38.

Zhang, J (2007). Barriers to water markets in the Heihe River basin in northwest China. Agricultural Water Management, 87, 32-40. 